\title{
The Role of the Business Environment, Supply Chain Management and Quality Management in Improving the Competitive Advantage of Small Business Retail
}

\section{Gusti Ketut Adi Winata1*, Gde Agung Satria², I Putu Agus Adnyana ${ }^{3}$}

1,2,3 Sekolah Tinggi Ilmu Ekonomi Satya Dharma

\section{A R T I C L E I N F O}

Article history:

Received 19 May 2019

Received in revised form

16 June 2019

Accepted 15 July 2019

Available online 29 August

2019

Keywords:

Business environment, supply chain management, quality manajement,

competitive adventage

\section{A B S T R A C T}

The purpose of this study is to find out how to increase competitive advantage through the Business Environment, Supply Chain Management, and Quality Management in small and medium businesses in Buleleng Regency by using a quantitative approach. This research is explanatory in the form of causality between variables. In this study examines the causal relationship between the business environment, quality management, supply chain management, and the competitive advantage of Small Business Retail in Buleleng regency. Data collection used in this study used a questionnaire method. The sampling technique is done by using purposive sampling technique. The results showed the business environment, Supply Chain Management, and quality management had a positive effect on competitive advantage.

\footnotetext{
* Corresponding author.

E-mail addresses: adiwinata@gmail.com (I Gusti Ketut Adi Winata)
} 


\section{Introduction}

The rapid development of technology has an impact on the business world, especially in the retail business, the development of retail businesses in several cities in Indonesia makes competition tighter. This needs to be examined and addressed so that the business world can continue to improve. Every business must have its own advantages to be able to compete and survive in business competition. In order for a business to win a competition, a company or business itself must have an advantage so that the business can have competitiveness and increase its competitive advantage with other companies or similar businesses. The existence of these advantages, it is expected that a business can survive and develop in the future. Increasing competition in the retail world causes company management to be more careful in choosing competitive strategies to be used. Companies are always looking for creative ideas to increase sales and fill the needs of their customers (Makmun, 2008).

Retail is all business activity which is done to sell goods or services directly to end consumers (Kotler, 1995). In addition, retail also connects the last users with sellers who provide merchandise. Competitive advantage can be enhanced through Supply Chain Management (SCM) practices and good relations with suppliers (Porter, 1985). Suppliers have a value chain that creates and communicates input that is bought and used in the company's value chain. Value chain activities are their own building blocks of competitive advantage. In the SCM literature, the role and performance of SCM in creating competitive advantage is undeniable (Ellinger. et al, 2000).

The relationship between suppliers, customers, and the company itself, must be managed properly so that the operations of a company can run smoothly and sustainably, a good and long-term relationship with suppliers and customers, and so that product distribution from upstream to downstream in time to last user. Rahmasari (2011) in her research stated that SCM had a positive and significant effect on the company's operational performance. To improve the company's operational performance, it is also necessary to have an SCM strategy implemented. If the SCM strategy is applied to the company it can improve the operational performance of a company.

Environmental factors play an important role for companies, especially in the creation and improvement of the company's competitive advantage. The change in the environment both internal and external require a company to be able to adapt to these changes so that the company can survive in business competition. Meanwhile, planning is a tool for adaptation and is also a determining factor for the company's operational performance so it is expected to create a competitive advantage. To determine the company's operational performance, a performance evaluation is carried out. Thus a success or failure in a company's operational performance is inseparable from the influence of the business environment (Erwin, 1994). Phillips (2000) shows a positive result between strategic planning and performance that results in competitive advantage.

Environmental dimensions include environmental munificence, environmental dynamism, and environmental complexity. Environmental munificence is the level of environmental support for the growth of the organization that is in it. Munificence is often measured on three conceptually scales namely the cost of producing, the availability of labor, and the level of competition. Environmental dynamism represents environmental conditions that are unpredictable (Ward et al, 1995). A dynamic environment is characterized by rapid and continuous changes in the environment in terms of demand, competitors, technology, and regulations such as inaccurate, unavailable, and outdated information. Whereas environmental complexity refers to the homogeneity of heterogeneity and concentration-dispersion from the environment that requires different production requirements for different market segments and levels of competition.

From the mastery of the company's business environment factors can identify the strengths and weaknesses owned, in other words the company will be able to achieve the goals set when the company's strengths exceed the weaknesses that are also able to turn weaknesses into strengths. The intended purpose is to optimize the practice of SCM (Jatmiko, 2004).

Applying good quality management can create competitive advantage. There are several concepts to improve quality management including the concept of TQM (Total Quality Management) in manufacturing companies, Six Sigma, and QMS (Quality Management Service) in service companies, and so forth. But in essence, all of them are the same. To reduce the level of disability so as to achieve perfect quality products. The results of quality management in the form of a good product can bring benefits to companies that come from higher sales revenue and lower costs, where the combination of the two results in profitability and company growth (Nasution, 2005). The company's goal in implementing quality management is to build success through differentiating products and services, low cost (efficient), and responding to market and consumer tastes (Tampubolon, 2004). According to Heizer (2004), building quality is a way to create profitability for companies. 
The development of modern and traditional retails have led to fierce competition between traditional retails and modern retails, as we know that traditional retails are increasing every day as well as modern retails. Based on BPS data in Table PT. Indomarco Prismatama from 2011 to 2017 continued to increase so that until 2017 it was recorded as 21 units spread across Buleleng regency, then followed by PT. Sumber Alfaria Trijaya, which was recorded in 2011 as many as 2 units and in 2017 increased to 25 units in Buleleng regency. This phenomenon makes this kind of traditional retail store threatened with bankruptcy.

Criteria for small business according to M. Tohar in his book Making Small Business (1999: 2) criteria for small and medium businesses from various aspects are as follows: Based on the total assets of small entrepreneurs are entrepreneurs who have a net worth of at most Rp 200,000,000 excluding land and buildings place to open a business; Based on total sales. Small-scale entrepreneurs are entrepreneurs who have a total net sales / year of at most Rp 1,000,000,000. Based on ownership status, small entrepreneurs are businesses in the form of individuals that can be incorporated or not incorporated, including cooperatives.

Small business retail is one of the important factors in supporting the regional economy. Evidenced by the category of the Development of the Role of the Wholesale and Retail Trade category of the Buleleng District's PDRB whose value reached $11.02 \%$ in 2017 . The retail trade category is the third largest contributor to the economy in Buleleng District in general (BPS, 2017). In addition to helping with the formation of PDRB, small business also play a role in reducing the number of unemployed in Indonesia through increasing employment absorption each year (Stefani et al, 2014). Seeing this, small business retail are expected to have a competitive advantage in order to be able to survive and also thrive in the retail business.

In BPS of Buleleng Regency, small business is divided into three, namely, mini stalls, shops and stores. In this study, researchers only examined one store, from year to year, the number of retail shops in Buleleng regency always increased or increased. The number of stores increased from 2012-2017 according to BPS in Buleleng regency. Although it continues to develop, its management tends to be still traditional, such as in terms of the layout of goods where in traditional retail stores the position of each item is randomly arranged according to the type of product, when viewed from payments to traditional retailers it still uses a calculator as a calculator, not using a card credit or ATM.

Seen from the perspective of existing theory and reality, there is a gap between theory and reality in this case traditional small business retail especially those in Buleleng District, even though traditional small business retail are also increasing in number but traditional small business retail are still experiencing a decrease in income due to the emergence and the development of modern retail in Buleleng District and the weak competitive advantage of traditional small business retail in Buleleng District so that they are unable to compete in competition. Seeing this, to be able to survive and develop, traditional small business retail, especially in the area of the Buleleng District must increase their competitive advantage by seeing, observing, and further researching the things that play a role in efforts to improve the business environment, SCM, and quality management.

The hypotheses contained in this study are:

H1: $\quad$ Business environment has a positive effect on supply chain management.

H2: $\quad$ Business environment has a positive influence on quality management.

H3: $\quad$ Business environment has a positive effect on competitive advantage.

H4: $\quad$ Supply chain management has a positive effect on competitive advantage.

H5: Quality management has a positive effect on competitive advantage.

\section{Methods}

The population in this study are all traditional business retail in the Buleleng District, which until the end of 2016 amounted to 3,104 units (BPS, 2016). The sample in this study are some traditional small business retail in Buleleng District. The sample taken of the study were 40 respondents. This refers to Rascow's theory which determines sample size by means of the number of variables multiplied by 10 , then 4 (variables) x $10=40$ respondents (Sekaran 2015). The sampling technique is done by using purposive sampling technique, which is the technique of determining the sample with certain considerations (Sugiyono, 2002), namely with the following criteria: 1) Self-owned of small business retail, 2) Small Business Retail independently managed, and 3)Small business retail which includes convenience stores (mini supermarket retail).

Data collection techniques in this study is using a closed questionnaire, which is an alternative answer predetermined by researcher. The analysis technique used in this study is a variance-based Structural Equation Modeling (SEM), which is famously called Partial Least Square (PLS). PLS uses a three- 
stage literacy process and each stage of literacy produces estimates. The first stage produces weight estimates, the second stage produces estimates for the inner model and outer model, and the third stage produces estimates of means and locations (constants). The evaluation of the PLS model is based on the measurement of predictions that have non-parametric properties. Therefore, the PLS evaluation model is carried out by assessing the outer model and the inner model.

\section{Result and Discussion}

This study uses SEM analysis techniques with the Generalized Component Analysis (GeSCA) method. Testing with this analysis technique is carried out in three stages. The first stage is the measurement of overall goodness of fit model with FIT, AFIT, GFI and SRMR tests. Goodness of fit test results can be seen in Table 1 .

Table 1. Goodness of Fit

\begin{tabular}{cccc}
\hline & Fit Model & Result & Conclusion \\
\hline FIT & $>50 \%$ & $57,6 \%$ & Fit \\
AFIT & $>0,5$ & 0,549 & Fit \\
GFI & $>0,9$ & 0,993 & Fit \\
SRMR & Close to Zero & 0,135 & Fit \\
\hline
\end{tabular}

Based on the results of the model tests in table 1 shows that this research model meets the fourth criteria overall model fit size. The second stage is the evaluation of the measurement model (outer model), namely the test of the validity of the indicator by looking at convergent validity and for the reliability test by looking at the value of composite reliability. Following are the results of testing the measurement models in table 2 .

Table 2. Outer Model

\begin{tabular}{|c|c|c|c|}
\hline Variable & Estimate & SE & $\mathbf{C R}$ \\
\hline Business Environment & \multicolumn{3}{|c|}{ AVE $=0.599$, D.G. Rho $=0.856$} \\
\hline BE1 & 0.865 & 0.057 & 15.081 \\
\hline BE2 & 0.772 & 0.082 & 9.384 \\
\hline BE3 & 0.752 & 0.105 & 7.131 \\
\hline BE4 & 0.697 & 0.168 & 4.143 \\
\hline Quality Management & \multicolumn{3}{|c|}{ AVE $=0.965$, D.G. Rho $=0.993$} \\
\hline QM1 & 0.986 & 0.005 & 184.312 \\
\hline QM2 & 0.983 & 0.007 & 147.176 \\
\hline QM3 & 0.974 & 0.012 & 83.365 \\
\hline QM4 & 0.989 & 0.004 & 229.808 \\
\hline Supply Chain Management & \multicolumn{3}{|c|}{ AVE $=0.560$, D.G. Rho $=0.864$} \\
\hline SCM1 & 0.813 & 0.096 & 8.502 \\
\hline SCM2 & 0.681 & 0.116 & 5.890 \\
\hline SCM3 & 0.752 & 0.081 & 9.245 \\
\hline SCM4 & 0.722 & 0.118 & 6.142 \\
\hline SCM5 & 0.767 & 0.073 & 10.464 \\
\hline Competitive Advantage & \multicolumn{3}{|c|}{ AVE $=0.573$, D.G. Rho $=0.841$} \\
\hline$\overline{\mathrm{CA} 1}$ & 0.607 & 0.238 & 2.553 \\
\hline CA2 & 0.847 & 0.088 & 9.585 \\
\hline CA3 & 0.754 & 0.105 & 7.188 \\
\hline CA4 & 0.799 & 0.096 & 8.324 \\
\hline
\end{tabular}

According to table 2, the convergent validity test results show that the loading factor of all construct indicators is above the criteria 0.5 and the CR value is significant above 1.96 at the 5\% significance level. The reliability test shows that the AVE value of all constructs is above the criteria 0.5 and composite 
reliability (D.G. rho) is above the criteria 0.7. It can be concluded that all constructs are valid and reliable. The third stage is evaluating the inner model (structural model) by looking at the coefficient of determination R-square (R2). Following are the results of the analysis of the coefficient of determination in table 3.

Table. 3 R square and coefficient of Determination

\begin{tabular}{ccc}
\hline Variable & R square & Coefficient of Determination \\
\hline QM & 0.0299 & $2,99 \%$ \\
SCM & 0.167 & $16,7 \%$ \\
CA & 0.153 & $15,3 \%$ \\
\hline
\end{tabular}

Based on the analysis of the coefficient of determination in Table 3 shows the coefficient of determination of quality management (QM) of $2.99 .4 \%$, which means that the level of variability of business environment variables based on tri hita karana is $2.99 \%$. Next the level of variability in the variable integrated quality management (SCM) which can be explained by the business environment is $16.7 \%$. Furthermore, the variability of competitive advantage (CA) that can be explained by the business environment, quality management and supply chain management is $15.3 \%$, while the rest is influenced by other variables at $84.7 .6 \%$ which are not included in this study.

Hypothesis testing is done through structural model testing by looking at the significance of the path coefficient (CR value) of each influence between constructs. The influence between constructs is significant if the CR value is greater than the t-table value of 1.96 at the $5 \%$ significance level. The results of hypothesis testing are shown in table 4 . Based on the results of the test of the influence of constructs as in table 4 shows that all hypotheses are accepted. The relationship of influence between constructs is only one that is declared significant, namely, the business environment has a significant effect on supply chain management.

Table 4. Hypothesis Test and Path Coefficient

\begin{tabular}{|c|c|c|c|}
\hline Path Model & Estimate & CR & Conclusion \\
\hline BE->QM & 0.173 & 1.093 & Accepted \\
\hline BE->SCM & 0.408 & 2.918 & Accepted \\
\hline $\mathrm{BE}->\mathrm{CA}$ & 0.011 & 0.060 & Accepted \\
\hline QM->CA & 0.133 & 0.608 & Accepted \\
\hline SCM->CA & 0.329 & 1.400 & Accepted \\
\hline
\end{tabular}

Based on the results of statistical calculations, it can be concluded that the construct of the business environment has a positive effect on the SCM construct, thus, the $1^{\text {st }}$ hypothesis in this study is accepted. If a company is in the right and strategic environment, it will have an impact on optimizing SCM, where SCM itself is a chain that includes suppliers, manufactures, warehousing, transportation, distribution, retail, and up to the hands of consumers. Echdar (2018) states that there is a positive and significant effect of location on the performance of retail small businesses in Makassar City. The results of the test of the influence of the business environment on quality management are the same as the research conducted by Faysollahi, et.all (2013) which concludes that the business environment influences quality management and there is a positive relationship between the business environment and quality management, in other words the $2^{\text {nd }}$ hypothesis is accepted.

The business environment has a significant positive effect on the construct of competitive advantage directly. Thus, the $3^{\text {rd }}$ hypothesis in this study was accepted. Setyowati (2015) in her research showed that the external environment and internal environment influence competitive advantage. Handriyani (2011) also stated in her research that there is a positive influence between external factors, on the competitive advantage of SMEs in Semarang Regency. Indicators of the business environment are business costs, labor availability, level of competition, and market dynamism. If this can be managed properly, the competitive advantage of a traditional retail SME in Buleleng District will increase too.

The SCM construct has a positive effect on competitive advantage. Thus, the $4^{\text {th }}$ hypothesis in this study was accepted. A good application of SCM in a Traditional Small Business Retail company in Buleleng District will be able to increase the competitive advantage of the company. The construct of quality management on competitive advantage shows a positive effect so that the $5^{\text {th }}$ hypothesis is accepted, previous research (Elshaer \& Augustyn 2015) concluded that there is a significant relationship between 
quality management and competitive advantage in other words the ability of Small Businesses to create quality output can create competitive advantage

\section{Conclusion}

Based on the results of the study it can be concluded that 1) The Business Environment has a positive effect on supply chain management; 2) Business environment has a positive influence on quality management; 3) Business environment has a positive effect on competitive advantage; 4) Supply chain management has a positive effect on competitive advantage; 5) Quality management has a positive effect on competitive advantage. The attention of Traditional Small Business Retail to the Business Environment, SCM, and Quality Management factors which are still low makes retailer unable to compete in their business with other competitors. It is expected that retailer will pay more attention to these three factors so that in the future Traditional Small Business Retail, especially in Buleleng District can have superior value or competitive advantage, because there have been many studies which state that these three factors greatly influence the efforts to create and increase the competitive advantage of a company.

\section{Reference}

Echdar, Saban. (2018). Strategi Usaha Kecil Ritel Untuk Meningkatkan Kinerja Dan Keunggulan Bersaing Berkelanjutan (Studi Kasus Di http://dx.doi.org/10.24034/j25485024.y2014.v18.i3.146

Ellinger, A.; Daugherty, P. \& Keller, S. (2000): "The relationship between marketing/logistics interdepartmental integration and performance in U.S. manufacturing firms: An empirical study"; Journal of Business Logistics; Vol.21 no.1.

Elshaer, Ibrahim A. and Augustyn Marcjanna M. (2015). Direct Effects Of Quality Management On Competitive Advantage. https://doi.org/10.1108/IJQRM-07-2014-0086.

Erwin, A., Koetin, (1994), Suatu Pedoman Investasi dalam Bisnis Bursa Efek di Indonesia, Jakarta : Bapepam, Depkeu.

Fayzollahi, Sadegh. Shirmohammadi, Alireza, and Latifian, Behzad. (2013). The Impact of Environmental Factors on Total Quality Management and Firm Performance: Evidence from Industrial Enterprises in Iran. http://www.irjabs.com/files_site/paperlist/r_1131_130817000941.pdf.

Handriani, Eka. (2011). Pengaruh Factor Eksternal, Entrepreneurial Skill, Strategi dan Kinerja Terhadap Daya Saing UKM di Kabupaten Semarang. Fakultas Ekonomi UNDARIS Ungaran.

Heizer, J. and Barry R. (2004). Operation Management, Seventh Edition, USA: Pearson Prentice Hall Inc.

Jatmiko, Rahmad Dwi, (2004). Manajemen Stratejik. Edisi 1. Cet. 2. Malang: UQM Press.

Kotler, Philip. (1995). Manajemen Pemasaran. Jakarta. : Rehanlindo.

M. Tohar, (1999), Membuat Usaha Kecil. Jakarta : Salemba Empat

Makmun, (2008), Pengembangan UKM Kreatif Untuk Meningkatkan Keunggulan Bersaing Universitas Diponegoro, Fakultas Ekonomi Universitas Diponegoro Semarang.

Nasution, M. N. (2005). Manajemen Mutu Terpadu: Total Quality Management, Edisi Kedua, Bogor : Ghalia Indonesia.

Phillips,P.A. (2000). The Strategic Planning/Finance Interface: Does Sophistication Really Matter?. Management Decison Vol 38/8.

Porter, M.E. (1985). Competitive Advantage : Creating and Sustaining Superior Performance : with a new introduction. New York : The Free Press. 
Rahmasari, Lisda. (2011). Pengaruh Supply Chain Management Terhadap Kinerja Perusahaan dan Keunggulan Bersaing. Majalah Ilmiah Informatika Vol. 2 No. 3. Fakultas Ekonomi Universitas AKI.

Sekaran, Uma. (2014). Metodologi Penelitian untuk Bisnis (Research Methods for Business). Buku 1 Edisi 4. Jakrta: Salemba Empat

Setyowati, Novita Wahyu. (2015). Pengaruh Lingkungan Eksternal Dan Lingkungan Internal Terhadap Keunggulan Bersaing Pada Industri Kecil Dan Menengah Di Bandung, Jawa Barat. https://doi.org/10.15408/ess.v5i1.2330.

Stefani, V dan Oki Sunarndi (2014), Peran Dependensi, Comitment, Trust dan Comunication Terhadap Kolaborasi Perusahaan dan Kinerja Perusahaan: Studi pendahuluan. 13(3). Jurnal teknologi.

Sugiyono. (2013), Metode Penelitian Kuantitatif Kualitatif dan R\&D, Bandung: Alfabeta.

Tampubolon, Manahan P. (2004). Manajemen Operasional. Jakarta : Ghalia Indonesia.

Ward, P.T. Bickford, D.J., Leong, G.K.. (1995). Business environment, operation strategy, and performance: an empirical study of Singapore manufacturers. Journal of Operation Management, 13 (2), 